\title{
Probiyotikler: Genel Özellikleri ve Güvenilirlikleri
}

\author{
Yağmur Koçak, Arzu Fındık, Alper Çiftçi \\ Ondokuz Mayıs Üniversitesi, Veteriner Fakültesi, Mikrobiyoloji Anabilim Dall, Samsun
}

Geliş Tarihi / Received: 08.08.2016, Kabul Tarihi / Accepted: 09.10.2016

\begin{abstract}
Özet: Bu derlemede hayvan ve insan sağlığında antibiyotiklere alternatif olarak kullanılmakta olan probiyotiklerin etkileri ve güvenilirlikleri ile beraber probiyotik olarak kullanılan mikroorganizmalar ve bu mikroorganizmalarda aranan özellikler hakkında bilgi verilmiştir.
\end{abstract}

Anahtar kelimeler: probiyotik, laktik asit bakterileri, güvenilirlik

\section{Probiotics: General Features and Safety}

\begin{abstract}
The effects and reliabilities of probiotics used in animal and human health as an alternative for antibiotics as soon as the microorganism used as a probiotics and the features of these microorganisms were reported in this review.
\end{abstract}

Key words: probiotic, lactic acid bacteria, reliability

\section{Giriş}

Probiyotik terimi "canlı için" (Latince "pro" ve "bios") anlamına gelmektedir. Güncel araştırmalar ve kullanım alanlarına bağlı olarak probiyotikler, kalitatif veya kantitatif olarak bağırsak mikroflorasını etkileyen veya immun sistemin durumunu değiştirerek yararlı etkilerini tetikleyen, insan ve hayvanlar tarafindan tüketilen canlı mikroorganizmalar" olarak tanımlanmaktadır [8]. Probiyotikler hakkındaki ilk çalışma 19. yüzyılın sonlarında, "probiyotiklerin isim babası" olarak anılan Nobel ödüllü Rus bilim adamı Elie Metchnikoff tarafından yapılmıştır. Metchnikoff fermente süt tüketimi ile uzun ömür arasında ilişki kurmuş ve sütte probiyotiklerin (laktik asit bakterilerinin) varlığını tespit etmiştir.

Prebiyotik terimi Gibson ve Roberfroid tarafindan, "kolon bakterilerinden birinin veya az bir kısmının çoğalması ve/veya aktivitesini etkileyerek yararlı bir etki oluşturan sindirilmeyen gıda maddesi" olarak tanımlanmış olup, "fonksiyonel gıda" ya da "nutrasotikler" olarak da adlandırılmaktadırlar $[9,25]$. Prebiyotikler, insan ve hayvan sağllğında kullanılabilen ve kolon bakterilerine olumlu yönde etki yapan karbonhidratlardır.

Sinbiyotikler, probiyotik ve prebiyotikleri bir arada içeren gida/besin veya katkı maddeleri olarak tanımlanmakta olup, probiyotik ve prebiyotiklerin sinerjik etkisi göz önüne alınarak geliştirilmişlerdir $[3,9]$.

Laktik asit bakterileri probiyotik olarak en çok kullanılan mikroorganizmalar olup, siniflandirmada 6 grup olarak (Lactobacillus spp., Bifidobacterium spp., Enterococcus spp., Streptococus spp., Leuconostoc spp., ve Pediococcus spp.) değerlendirilmektedirler [27]. Ayrica, Bacillus, Saccharomyces ve Aspergillus türleri de probiyotik olarak kullan1lan mikroorganizmalar arasında bildirilmektedir.

Laktobasiller fakültatif anaerobik olup $\mathrm{pH}$ 3,0'e kadar tolerans gösterir, böylece düşük mide pH'sında canlılıklarını koruyarak, bağırsak kanalına geçip etkilerini burada gerçekleştirirler. Duodenumda safra tuzlarından etkilenmezler. Ayrıca, pek çok Lactobacillus suşu 45$48^{\circ} \mathrm{C}$ gibi yüksek 1si ve basinca nispeten dayanıklı olduğundan yem yapım işlemleri sırasında 1S1 ve basınçtan etkilenmeyerek canlılıklarını koruyabilir [10].

Enterokoklar, fakültatif anaerobik, $10^{\circ} \mathrm{C}$ ve $45^{\circ} \mathrm{C}^{\prime} \mathrm{de}, \mathrm{pH} 9,6$ ' da, \% 6,5 NaCl' de \% 40 safra tuzunda gelişebilen bakterilerdir. E. faecium ve $E$. $f a-$ ecalis, bağırsak hastalıklarındaki etkileri nedeniyle probiyotik olarak kullanılmaktadır. Probiyotik olarak kullanımları bakteriyosin üretimine dayanmakta 
olup, patojen mikroorganizmalara direnç gen aktar1$\mathrm{m} 1$ ihtimallari nedeniyle kullanımları sorgulanmaktadir [19].

Bifidobakteriler, insan ve hayvanların bağırsak florasında ve kanalizasyon sularında bulunurlar. İshal vakalarında, immun uyarım için, anti-mutajen ve antikolesterojenik olarak kullanılırlar. Ayrıca vitamin sentezinde de aktiftirler [19].

\section{Mikroorganizmaların probiyotik özellikleri}

Probiyotik olarak kullanılacak olan mikroorganizmaların verildiği canlılarda bulunan diğer mikroorganizmalara karşı etkili olamları ve konakçıya yararları etki göstermeleri en önemli özellikleridir. Bunların yanı sıra probiyotik olarak kullanılması düşünülen mikroorganizmaların diğer bazı özellikleri de bulundurmasi gerekmektedir. Probiyotiklerin insan ve hayvanda yan etki oluşturmamaları ve dolayısı ile güvenilir olmaları beklenmektedir. Dolayısı ile bu mikroorganizmalar patojenik olmamalı ve toksin üretmemelidir. Ayrıca, aktarılabilir antibiyotik direnç genleri içermemeleri de barsak floras1 için önemlidir. Probiyotik mikroorganizmaların stabilitesi yüksek olmalı ve düşük $\mathrm{pH}$ ve safra tuzları gibi olumsuz çevre koşullarından etkilenmeden bağırsakta metabolize olmalıdır. Verildikleri canl1nın bağırsak hücrelerine adheze ve kolonize olabilmelidir. Probiyotik mikroorganizmaların ürettikleri antimikrobiyel maddeler vasitasiyla patojen bakterilere karşı antagonistik etki göstermeleri gerekmektedir. Antibiyotiklere dirençli olmalıdır ve bağırsakta gelişen hastalıkların tedavisi için kullanılan antibiyotiklerden etkilenmemelidir. Bu özellikleri nedeniyle de antibiyotik kullanımına bağlı olarak şekillenebilen diyare gibi semptomlar gösteren hastalıklarda bağırsak florasını düzenlemek amacı ile kullanılmaktadır. Canlı hücreler halinde ve tercihen fazla sayıda bulunmalı ve bağırsak ortamında canlı kalarak metabolize edilebilmelidir. Probiyotiklerin birden fazla mikroorganizma içeren karışımların hazırlanmasına uygun olmaları ve üretim ve depolama işlemleri sırasında canlılığını ve aktivitesini korumalar1 istenmektedir [5,30,31].

\section{Probiyotiklerin etkileri}

Probiyotiklerin rasyona katılmaları sonucunda hayvanlarda canlı ağırlık artışının artığı, yemden yarar- lanmanın iyileştiği, üretimin yükseldiği, gastrointestinal hastalıkların azadığı gözlenmesine rağmen etki şekilleri konusunda halen belirsizlikler bulunmaktadir.

Patojen bakterilerin sayısını azaltma: Probiyotik mikroorganizmalar, E. coli gibi diğer enteropatojenler için istenmeyen bir ortam oluşturup, bu grup mikroorganizmalara karşı antagonistik etki oluştururlar. Probiyotik mikroorganizmaların çoğunluğu, başta laktik asit olmak üzere, asetik ve formik asit gibi organik asitler üreterek bağırsak pH'sını düşürürler. Böylece Gram negatif patojen bakterilerin üremesini engelleyen bir ortam oluştururlar [28].

Probiyotik suşlar hidrojen peroksit, organik asit, bakteriosin gibi etken maddeler sayesinde antibakteriyal özellik gösterirler [20].

Probiyotik bakteriler tarafından üretilerek Gram negatif ve pozitif bakteriler ile mantarlara karşı geniş spektrumlu antibakteriyel etki gösteren bileşikler bildirilmiştir $[6,13]$.

Besin elementleri için rekabet: Probiyotikler, patojen bakterilerin çoğalmak için gereksinim duydukları besinleri tüketirler ve bu bakterilerin üremelerini inhibe ederler [2].

Adezyon mekanizması: Probiyotiklerin intestinal sistemde patojen mikroorganizmalara karşı bir bariyer oluşturmak suretiyle bu mikroorganizmaların epitelyal hücrelere adheze olmasını engellediğ düşünülmektedir.

Laktik asit bakterilerinin intestinal epitel hücrelere adezyonu çeşitli yüzey determinantları (elektrostatik ilişkiler, hidrofobisite, sterik kuvvetler, lektinler, lipoteikoik asit, vb.) [26].

Toksin ve patojenlerin bağlanmasının engellenmesi, müsin gibi konak faktörlerin uyarımı ya da reseptörlere kompetetif bağlanma gibi mekanizmalar bildirilmesine rağmen, inhibisyon mekanizması henüz tam olarak açıklık kazanmamıştır [21].

İmmun sistem üzerine etki: Probiyotiklerin son yılarda ortaya atılan önemli etkileri de "immunostimulan" etkileridir. İntestinal epitel hücreleri, kan lökositleri, B ve T lenfositleri ve immun sistemin yardımcı hücrelerinin tamamı probiyotiklerden etkilenir. İmmunomodülatör özelliğe sahip bakteriyel ürünler arasında endotoksik lipopolisak- 
karidler, peptidoglikanlar ve lipoteikoik asitler yer almaktadır. Gram pozitif bakterilerin, lipoteikoik asitleri epitelyum hücre membranlarına yüksek affinite gösterirken aynı zamanda diğer antijenler için taşıyıcı rol de oynayabilir ve immun cevabı uyaracakları hedef dokulara bağlar.

Probiyotikler, proinflamatuar sitokinlerinin ve kemokinlerin gelişmesinde anahtar rol oynamaktadir [24].

Probiyotiklerin bulunması, mukozal immun sistemde, antikor üretimini arttırmak, fagositoz ve NK hücrelerinin aktivitesini artırmak ve T hücre apoptozisini indüklemek gibi birçok modifikasyonlara neden olur [14].

Antikarsinojenik etki: Beslenmenin kanser oluşumunda önemli bir etken olduğu bilinmekte olup, probiyotik mikroorganizmaların beslenmede kullanımının kanser riskini azaltabildiği bildirilmiştir [12,29]. Probiyotik mikroorganizmaların başta bağırsaklar olmak üzere diğer organlarda mutajenik etkileri engellemesi nedeniyle antikarsinojenik etkileri olduğu ortaya konulmuştur [23].

Antikolestrol etki: Probiyotik bakterilerin safra tuzlarını serbest asitlere parçalamaları ve intestinal sistemden hızlı bir şekilde uzaklaştırmak suretiyle serum kolesterolünün düşürülülmesinde etkili olduğu düşünülmektedir. Kolesterolün düşürülmesinde 2 mekanizmanın etkili olduğu bildirilmektedir. Bildirilen ilk mekanizmada serbest safra tuzlarının vücuttan atılması ve kolesterolden yeni safra asitlerinin sentezinin azaltılması ile total kolesterol seviyesinin düşürülebileceği bildirilmektedir. Diğer bir görüşe göre, probiyotik bakterileri tarafindan üretilen asitler $\mathrm{pH}$ 'yı düşürmekte ve dekonjuge safra tuzları da kolesterolün presipitasyonuna neden olmaktadır .

Antibiyotik ilişkili diyareler üzerine etkileri: Oral yolla alınan antibiyotikler patojen mikroorganizmalar ile beraber barsak florasında bulunan yararlı bakterilere de etki gösterirler ve buna bağlı olarak antibiyotiğe bağlı diyare şekillenebilir [11]. Ağız yoluyla vücuda alınan mikroorganizmaların gastrointestinal sistemden geçişleri sırasında canl1lıklarını korumalarını engelleyen stres faktörlerinden biri antibiyotiklerdir. Probiyotik bakteriler ve bu bakterilerin kullanılmasıyla hazırlanan ürünler bağırsak sisteminde antibiyotik kullanımına bağlı olarak oluşan kolitlerin iyileştirilmesinde kullanılabilmektedir [17].

Besin sentezi ve biyoyararlanım: Probiyotik mikroorganizmalar lipaz, proteaz, amilaz, betaglukanaz gibi yemlerin sindirimine yardımc olan enzimler salgılayarak ve B grubu vitaminler (niasin, biotin, pridoksin, pantotenikasid, folik asit, riboflavin, B12) sentezleyerek sindirime katkıda bulunurlar $[7,15]$.

\section{Probiyotiklerin güvenilirlikleri}

Günümüzde ticari probiyotik ürünler hakkındaki mevcut bilgiler bu ürünlerin güvenilir olduklarını göstermektedir [18,22]. Bununla birlikte, potansiyel yeni cins ve türlerin probiyotik ürün oluşturmak amaciyla seçiminde, Avrupa Birliği tarafindan önerilen zorunlu güvenlik kriterlerine dikkat edilmesi gerekmektedir. Probiyotik ürünlerin güvenilirliğinde, üretilecek olan gidanın fenotipik ve genotipik özellikleri ile bu mikroorganizmaların gidalarda kullanımının geçmişi konusunda elde bulunan veriler temel kriterler olarak değerlendirilmektedir $[1,32]$.

Avrupa Birliği ülkelerinde probiyotiklerin güvenilirliği ve teknolojik özellikleri çok geniş kapsamlı iki projede araştırılmıştır. "Nordic projesi" ve Prodemo (FAIR CT96-1028) projesi [16].

Genel olarak probiyotiklerin güvenilirliği konusunda göz önünde tutulması gereken kriterler şu şekilde özetlenmektedir:

1. Üretici firma ürettiği gıdanın güvenilirliğinden birinci derece sorumludur. Probiyotik gidalar en az diğer gıdalar kadar güvenilir olmalıdır.

2. Probiyotik mikroorganizmalar yeni bir ürün oluşumunda kullanılacakları zaman yasal olarak onaylanmış olmaları gerekmektedir.

3. Bir suş probiyotik olarak uzun zamandır güvenilir bir şekilde kullanılıyorsa, gıda üretiminde ilk defa kullanılacak yeni suşlarla aynı işleme tabi tutulmaz.

4. Hiçbir suşu patojen olarak belirlenmemiş olan mikroorganizmalar ile uzun yıllardır probiyotik olarak güvenle kullanılan suşlar probiyotik üretiminde güvenilir kabul edilmekte ve yeni ürün üretiminde kullanımına izin verilmektedir. 
5. Hiçbir suşu patojen olarak belirlenmemiş ama güvenilir bir kullanım geçmişi olmayan suşlar probiyotik üretiminde kullanılabilir. Ancak bunların yeni ürün oluşumunda ilk defa izole edilen suşlarla aynı işlemi görmesi gerekmektedir.

6. Probiyotik potansiyeli olan suş, patojenik suşları da olduğu bilinen bir türe ait ise yeni bir ürün üretiminde kullanılmadan önce çok iyi araştırıldıktan sonra kullanılmalıdır.

7. Antibiyotik direnç genleri taşıyıp aktarabilen suşların probiyotik olarak değerlendirilmemelidir.

8. Güvenilir bir probiyotik seçiminde belki de en önemli kriter, suşun kesin olarak tanımlanmış olmasıdır. Bu amaçla günümüzde DNA-DNA hibridizasyon teknikleri veya $16 \mathrm{~S}$ rRNA dizi analiz teknikleri kullanılmalıdır. Taksonomik analizleri gelişmiş yöntemler kullanılarak tanıları doğru bir şekilde yapılmayan suşlar probiyotik olarak kesinlikle satılmamalıdır [4,32].

\section{Sonuç}

Hayvan ve insan sağlığında farklı etki şekillerine bağlı olarak probiyotik, prebiyotik ve sinbiyotikler birçok fayda sağlamaktadır. Probiyotiklerin akut bir hastalığın tedavisinde antibiyotiklerin yerini alması düşünülmese de koruyucu tedavide antibiyotiklere alternatif olarak kullanımı mümkündür. Gelecekte özellikle hayvan sağlığında bunların kullanımlarının daha yaygın hale gelmesi sonucunda verim artışının sağlanması muhtemeldir. Dolayısıyla, probiyotiklerin yeme katılması ve depolanması esnasında canlılıklarının korunmasının sağlanması, diğer katk1 maddeleri ile birlikte kullanılma olasılıklarının araştırılması ve bu araştırma sonuçlarının pratiğe aktarılmasının ülkemiz hayvancılığının daha sağlıklı ve güvenilir olması için önemli olduğu düşünülmektedir.

\section{Kaynaklar}

1. Başyiğit G, (2004). Bazı laktik asit bakterilerinin probiyotik olarak kullanılma özellikleri. Süleyman Demirel Üniversitesi Fen Bilimleri Enstitüsü Gıda Mühendisliği Anabilim Dalı Yüksek Lisans Tezi, 96s, Isparta.

2. Castagliuolo LM, Riegler MF, Valenick I, La Mont JT, Pathoulakis C, (1999). Saccharomyces boulardii; protease inhibits the effects of Clostridium difficile toxins $\mathrm{A}$ and $\mathrm{B}$ in human colonic mucosa. Infect Immun. 67, 302-307.
3. Douglas LC, Sanders ME, (2008). Probiotics and prebiotics in dietetics practice. J Am Dietetic Assoc. 108, 510-521.

4. Dunne C, Murphy L, Flynn S, O’Mahony L, O’Halloran S, Feeney M, Morrissey D, Thornton G, Fitzgerald G, Daly C, Kiely B, Quigley EMM, O' Sullvan GC, Shanahan F, Collins JK, (1999). Probiotics: From myth to reality. Demonstration of functionality in animal models of disease and in human clinical trials. Antonie van Leeuwenhoek. 76, 279-292.

5. Ezema C, (2013). Probiotics in animal production: A review. J Vet Med Anim Health. 5(11), 308-316.

6. Fox SM, (1988). Probiotics: intestinal inoculants for production animals. Vet Med. 83, 806-830.

7. Fuller R, (1989). A review. Probiotics in man and animals. J Appl Bacteriol. 66, 365-378.

8. Fuller R, (2004). Reasons for the apparent variation in the probiotic response. Biologist. 51(4), 232.

9. Gibson GR, Roberfroid M, (1995). Dietary modulation of the human colonic microbiota: introducing the concept of prebiotics. J Nutr. 125, 1401-1412.

10. Gilliand SE, (1984). Importance of bile tolerance of Lactobacillus acidophilus used as a dietary. J Dairy Sci. 67, 3045-3051.

11. Gönç S, Akalın A, (1995). Yoğurtta canlı olarak bulunan Lactobacillus acidophilus ve Lactobacillus bifidus'un organizma ve sağlık üzerine etkisi. İzmir, Proje No: VHAG1168.

12. Hirayama K, Rafter J, (1999). The role of lactic acid bacteria in colon cancer prevention: mechanistic considerations. Antonie van Leewenhoek, 76, 391- 394.

13. Kim CJ, Namkung H, An MS, Paik IK, (1988). Supplementation of probiotics to the broiler diets containing moldy corn. Korean J Anim Sci. 30, 542-548.

14. Kognoff MF, (1993). Immunology of the intestinal tract. Gastroenterol. 105, 1275-1280.

15. Kung L, (1990). Microbes and enzymes. Feed Int. 11(8), 10-16.

16. Leroy F, deVuyst L, (2004). Lactic acid bacteria as functional starter cultures for the food fermentation industry. Trend Food Sci Technol. 15, 67-78

17. Marteau P, Minekus M, Havenoar R, Veld JHJ, (1997). Survival of lactic acid bacteria in a dynamic model of the stomach and small intestine: Validation and the effects of bile. J Dairy Sci. 80, 1031-1037.

18. Mattila-Sandholm T, Matto J, Saarela M, (1999). Lactic acid bacteria with health claims- interactions and interference with gastrointestinal flora. Int Dairy J. 9, 25-35.

19. Mombelli B, Gismondo MR, (2000). The use of probiotics in medical practise. Antimicrob Agent Chemother. 16, 531-536.

20. Ouwehand AC, Kirjavainen PV, Shortt C, (1999). Probiotics: mechanisms and established effects. Int Dairy J. 9, 43-52.

21. Rastall RA, Gibson GR, Gill HS, (2005). Modulation of the microbial ecology of the human colon by probiotics, prebiotics and synbiotics to enhance human health: An over- 
view of enabling science and potential applications. FEMS Microbiol Ecol. 52, 145-152.

22. Salminen S, vonWrigt A, (1998). Current probiotics- safety assured? Microbial Ecol Health Dis. 10, 68-77.

23. Sanders ME, (1999). Probiotics. Food Technol. 53, 67-77.

24. Saxelin M, Tynkkynen S, Mattila-Sandholm T, (2005). Probiotic and other functional microbes: from markets to mechanisms. Current Opin Biotechnol. 16, 204-211.

25. Schrezenmeir J, de Vrese M, (2001). Probiotics, prebiotics, and synbiotics-approaching a definition. Am J Clin Nutr. 73(2 Suppl), 361S-364S.

26. Servin AL, Coconnier MH, (2003). Adhesion of probiotic strains to the intestinal mucosa and interaction with pathogens. Best Pract Res Clin Gastroenterol. 17(5), 741-754.

27. Tannock GW, (1997). Probiotic properties of lactic acid bacteria: plenty of scope for fundamental R\&D. Tibtech. 15, 270-274.
28. Vanbelle N, Teller E, Focant M, (1990). Probiotics in animal nutrition: a review. Arch Anim Nutr. 40, 543-567.

29. Williams GM, Wynder EL, (1996). Diet and cancer: A synopsis of causes and prevention stratagies. In 'Nutrition and Press, Inc., Boca Raton, Fla.

30. Yıldırım Z, Yıldırım M, (2000). Probiyotik özellik gösteren bifidobakteriler. Süt ve Süt Ürünleri Sempozyumu (Ed. M. Demirci), Tekirdağ, 266-271.

31. Y1lsay TÖ, Kurdal E, (2000). Probiyotik süt ürünlerinin beslenme ve sağllk üzerindeki etkisi. VI. Süt ve Süt Ürünleri Sempozyumu (Ed. M. Demirci), Tekirdağ, 279-286.

32. Zhou JS, Shu Q, Rutherfurd KJ, Prasad J, Birtles MJ, Gopal PK, Gill HS, (2000). Safety assessment of potential probiotic lactic asid bacterial strains Lactobacillus rhamnosus HN001, L. acidophilus HN017, and Bifidobacterium lactis HN019 in BALB/ c mice. Int J Food Microbiol. 56, 87-96. 